\title{
Esotericism's Expanding Horizon: Why This Book Came to Be
}

\author{
Egil Asprem and Julian Strube
}

The academic study of esotericism is currently undergoing a phase of expansion and diversification. This is true whether we look at the topics, geographical regions, and subject languages of new research projects in the field, at the disciplines involved in its study, or the demographic composition of its scholars. The past decade has seen monographs, anthologies, and journal special issues on topics such as African-American esotericism (Finley, Guillory and Page, eds., 2014), esotericism in South America (Bubello, 2010), esotericism in South Asia (Djurdjevic, 2014), esotericism in Scandinavia (Bogdan and Hammer, eds., 2016), global esotericism (Bogdan and Djurdjevic, 2014), contemporary esotericism (Asprem and Granholm, eds., 2013), esotericism in antiquity (Burns, ed., 2015), Islamic esotericism (Saif, 2019), cognitive approaches to esotericism (Asprem and Davidsen, 2017), ethnographic approaches to esotericism (Crockford and Asprem, 2018), feminist and queer analyses of esotericism (Hedenborg White, 2019), and so on. We see new forays into literary studies, art history, colonial and global history, history and sociology of science, the study of popular culture, and many other domains. The study of esotericism always had interdisciplinary aspirations, but recent years have accelerated this trend. With it comes an increased need for generalists in the field to read broadly across an expanding number of disciplines.

Despite this onward rush into new territories and fields of inquiry, the central assumptions, terminology, and theoretical and methodological approaches of the field do not seem to have followed suit. On the contrary: longstanding assumptions and biases about esotericism as "Western," "rejected," "oppositional," and "elite" are becoming barriers to developing the research perspectives necessary for coming to terms with esotericism's expanding horizon. Despite understanding itself as an open and interdisciplinary field, we hold that a majority of work done under the banner of "Western esotericism" displays a tendency toward internalism and isolation from bigger debates in the humanities at large. This issue was in fact raised during the definition debate in the early 2000 s (cf. Okropiridze, 2021), particularly by Kocku von Stuckrad (see e.g. von Stuckrad, 2005; 2008). In a keynote lecture to the First International Conference on Contemporary Esotericism in Stockholm in 2012, with many of the leading scholars in the field present, von Stuckrad (2012) explicitly 
pointed to the field's lacking engagement with theoretical debates about some of its very key concepts, such as secrecy, knowledge, identity, polemics, and the West. We observe that the debate has receded over the past decade, while the field and its key terms remain as undertheorized as they were before.

The current book is conceived from what we see as an urgent need to question, rethink, and revise existing approaches in the study of esotericism. More than simply discussing explicit theorizing, however, what we call for is a deeper, critical look at the often implicit and tacit biases that are built into the field's key concepts. These, we hold, are obstacles, not only to the advance of scholarship within the field, but also to its relationship with scholars outside of it. It is only through the "tough love" of interrogating such biases that the field may flourish for another generation.

\section{1 \\ The Tacit Biases of "Western Esotericism": Some Examples}

By way of introduction, we may briefly consider some of the most obvious implicit biases attached to the two terms that make up "Western esotericism." The term "Western" has recently attracted a lot of attention, including a plenary panel debate at the conference of the European Society for the Study of Western Esotericism (ESSWE) in Amsterdam in 2019 (for the published debate leading up to it, see especially Pasi, 2010; Granholm, 2013; Asprem, 2014; Hanegraaff, 2015; Roukema and Kilner-Johnson, 2018; Strube, 2021). The term was originally adopted as a qualifying adjective intended to cordon off the field from universalist and perennialist approaches that had assumed a timeless and essential esotericism, manifesting across history in many separate cultures. It was conceived as a marker of historical specificity rather than a precisely defined geographical or cultural area. This, in turn, was linked with a historicist "empirical turn" in the study of esotericism in the early 199os; out went metaphysical notions of timeless wisdom and transcendent experience, in came a focus on primary sources trapped in the contingency of specific historical circumstances.

At least that was the idea. The newfound identity of a "Western" esotericism construed in historicist rather than essentialist terms also came to introduce a new and largely tacit form of cultural essentialism: whatever else esotericism might have been, it was uniquely "Western," and would retain this unique characteristic no matter where in the world "it" travelled. Tied to widespread exceptionalist assumptions about "Western civilization," the term came to obscure the differences among the material labelled "Western" (e.g. South American, as demonstrated by Villalba [2021], Scandinavian, or South Asian 
"Western" esotericism) while it accentuated differences between this Western esotericism and related materials elsewhere.

It is worth pointing out that this logic has not only barred a comparative assessment of purely analogous forms of practice in "non-Western" contexts; it has also shut the door on cases where there are obvious historical links between "Western" and "non-Western" materials. For example, in the Dictionary of Gnosis and Western Esotericism (2005) the choice was made to exclude both Jewish and Islamic currents from "the West" (Hanegraaff, 2005, p. xii), a choice which, although defended on "pragmatic" rather than theoretical or even historical grounds, did correspond with the explicit demarcation of "the West" proposed by Antoine Faivre in the early 1990s (cf. Pasi, 2007, pp. 152-4, 164). Since then, the study of Jewish Kabbalah has thrived in parallel with, but has still not been completely integrated into, the study of esotericism, while the study of Islamic esotericism has remained all but ignored until very recently (see especially Saif, 2019; Melvin-Koushki and Gardiner, eds., 2017).

As a consequence the entire Islamic world has been treated as a "carrier civilization" of mostly Greek (and hence, one assumes, "properly Western") material that would only become Western esotericism when discovered by Latin scholars in the fifteenth century (cf. Saif, 2021), while Jews have been relegated to minor supporting acts or "influences" on the same Western actors. This is not only problematic when considering the often somewhat ahistorical approaches to esotericism in (Greek) antiquity (cf. Burns, 2021). When central currents such as kabbalah or even alchemy, which truly came into its own in a medieval Islamic context (Principe, 2012), are defined out of "Western" esotericism, it is hard to avoid the conclusion that the exclusively "Western" identity of esotericism is an artefact of how the field has been theorized. It is a product of scholarly choices.

The cultural essentialism that sneaks in with the term "Western" has also hampered a comprehensive understanding of the consequences of colonialism and colonial exchanges for esotericism. This is particularly evident in the diffusionist position that some scholars have recently advanced in response to criticisms of the demarcation. Acknowledging that "Western esotericism" has to be viewed as a global phenomenon, at least in the modern period, Wouter Hanegraaff has claimed that this was the result of its unilateral export into a world of passive recipients, who became part of the history of esotericism only after their "Westernization" (Hanegraaff, 2015, p. 151). Here the implicit and unreflected essentialism of Western esotericism becomes clearly tangible: "mutations" have occurred in "originally European esoteric or occultist ideas" when they have been disseminated outside the West; these have then "traveled back to the West, only to be (mis)understood there as the 'authentic' voices 
of non-Western spiritualities." Hence, Hanegraaff calls for the investigation of the "globalization of Western (!) esotericism" (Hanegraaff, 2015, p. 86, original emphasis). Apart from its (cultural) essentialist understanding (i.e., esotericism is alway Western at core, even after "mutations" occur in "non-Western" contexts), this viewpoint is shaped by implicit assumptions about "authenticity" (cf. Cantú, 2021) and actively overlooks the agency of "non-Western" actors. When disembodied ideas are seen to simply "mutate" in a different environment, no attention is given to the local minds and bodies in which such ideas existed, or the intentions and agendas through which they were adopted, adapted, and eventually disseminated further. Behind that viewpoint stands the choice to prioritize elements that are assumed, on a vaguely canonical basis, to be "Western" over the role of "non-Western" elements. Only then can it be claimed that the result of the exchange was "Western" at heart. Again, we are dealing with an artefact of the pre-theoretical assumptions built into "Western esotericism." Scholarship on the Theosophical Society is an instructive case in point, as it tends to exclusively focus on the role of "Western," white Theosophists while practically ignoring the many "non-Western" people who, like in India, actively participated in shaping Theosophy (Strube, forthcoming; 2021).

The conceptualization of "Western esotericism" has concrete ramifications, not only for the interpretation of sources, but also for how sources are selected in the first place. This directly relates to the problem that "Western," as a marker of identity, is often coded white (cf. Bakker, 2019; Bakker, 2021; Page and Finley, 2021). It is pertinent to ask how whiteness bias has structured research on esotericism, not only in its relative lack of interest in asking questions about race, but also in its very selection of material and construction of historical narratives (Bakker, 2019, p. 9; Gray, 2019, pp. 206-216). That the link between Western and whiteness has become even stronger in the identity politics of the last couple of decades only increases the urgency of reflecting on how racialist logics operate in the field, and even on how the field's own narratives stake out positions in broader political discourses on race, culture, and identity.

While the pre-theoretical baggage of the adjective Western is thus exceptionally heavy, ${ }^{1}$ the term "esotericism" is itself loaded with a variety of assump-

1 On this matter our assessment is diametrically opposed to that of Hanegraaff, who claims that "the theoretical baggage of 'Western esotericism' is, in fact, quite light" (Hanegraaff, 2015, p. 28). He is only able to argue this by separating the term from "specific assumptions about the nature of 'the West,"' which we hold is impossible to do. Even if it were possible, it would not counter the problem of cultural essentialism discussed above. 
tions that must be unpacked. Let us just consider two of them. First of all, scholars in the field have often pointed out that their subject is associated with the weird, unconventional, irrational, and heterodox. This feature is now seen as the product of processes of exclusion that form central parts of current theoretical models of esotericism as "rejected knowledge" (e.g. Hanegraaff, 2012). Secondly, there is also an awareness that the term has been shaped in important ways by insider, that is to say "emic," attempts at constructing tradition-spinning imaginary webs of relations and transmissions that link mystery cults, Gnostics, and Knights Templars to Rosicrucians, contemporary initiatic orders, and "wisdom schools" of all sorts.

While both features are well-known and frequently problematized in the field, there has been surprisingly little reflection about how they still inform the way scholars select, describe, categorize, and even explain the supposedly "related currents" that they study. Despite an often explicit distancing from insider constructions of tradition and an emphasis on the need to contextualize and complicate standard narratives, lists of typical "esoteric currents" produced by scholars remain predictably stable. And while admonitions to resist the temptation of conceiving esotericism as a deviant "counterculture" have been around for twenty years (e.g. Hanegraaff, 20o1), we can still find the rejection of "esotericism" grandiosely described as "the most fundamental" grand narrative of "Western culture" as a whole (Hanegraaff, 2019a, pp. 149-150).

It is important to note that the two features- "deviant," "anti-Establishment" knowledge and grand tradition narratives-are frequently connected by esoteric spokespersons. It is this connection that allows occultists, new agers, and contemporary conspirituals alike to position themselves as oppositional as well as members of an enlightened elite (cf. Asprem and Dyrendal, $2015 ; 2018$ ). Rather than complicating such narratives and analyzing the strategic work that they perform in a broader societal context (cf. Crockford, 2021), scholarly accounts produced in the framework of Western esotericism have tended to reinforce and perpetuate them. When emphasizing how esoteric spokespersons have in fact been marginalized, scholarly narratives can themselves be read as counter-canonical descriptions of "noble heretics," approximating a succession of "great men" whose relevance for the field is precisely that each stands on the shoulders of another (misunderstood or marginalized) giant (cf. Asprem, 2021). In terms of selection of sources, then, it can sometimes be difficult to distinguish an academic historical narrative from an insider construction of esoteric tradition (see for example textbook introductions such as Goodrick-Clarke, 2008; Versluis, 2007).

Critical debates pertaining to these issues are rarely taken to their logical conclusion, as the implications of the rejected knowledge narrative illustrates. 
This is also the case with the "Western" demarcation, which in fact is related to insider conceptualizations of esotericism as "tradition." Although it was pointed out already a decade ago that the notion of "Western esotericism" is itself a polemical occultist construct of the late nineteenth century (Pasi, 2010; cf. Strube, 2017), this has not led to the critical reflection on its use that one might have expected. We hold that these examples illustrate a deeper contradiction at work in the scholarly discourse on esotericism. On the one hand, scholars have been careful to state that their aim is to destabilize the category itself by showing how historical actors that only appear through its prism (because they have otherwise been neglected or rejected) are in fact fully understandable in light of the prevailing discourses of their times; on the other, the term continues to function as a convenient way to group, categorize, and relate "esoteric currents" under an umbrella that, for all practical reasons, sets them apart from those other fields and orders them into an alternative canon of "(Western) esoteric thought." There is a widespread tendency to insist that the latter remains useful for pragmatic reasons, perhaps as a kind of "strategic essentialism" that makes the field visible and gives it a voice (cf. Roukema and Kilner-Johnson, 2018, p. 112). However, the field has already been established quite successfully for some time, and continues to produce work demonstrating that there is little or nothing sui generis "esoteric" about the figures and currents that feature as major representatives of "Western esotericism" (e.g. Stengel, 2011 about Swedenborg; Strube, 2016 about Éliphas Lévi). Ironically, then, the conceptualization of "Western esotericism" prevents the desired normalization of the field's subject matter; it may even function as a self-fulfilling prophecy with regard to the marginality of its subjects-and, crucially, of the field itself.

\section{Preventing the Self-Marginalization of the Field}

The latter point concerning the field's self-marginalization is a key reason why we have assembled this volume. The internalist ordering of relevant authors, currents, and concepts that the theoretical apparatus of "Western esotericism" constructs and enforces is creating a barrier for dialogue with scholars in other fields, who either study the same subjects from an entirely different angle (for example as classicists, experts of early modern intellectual history, or historians of colonialism), or deal with the same broader issues that esotericism scholars highlight in their own materials (e.g. heterodoxy, initiation, ancient wisdom narratives, colonial and intercultural exchanges). It is telling that scholars have been able to produce great work on "esoteric" subjects with- 
out the concept of "Western esotericism." This is obvious if we think about classics that were written long before the field even existed (e.g. Thorndike, 1923-1958; Yates, 1964). More importantly for the present context, the same holds true for a rapidly expanding literature of cutting-edge research on what esotericism scholars would consider part of their field, covering a vast spectrum from Theosophy (Viswanathan, 1998; Bevir, 200o; van der Veer, 2001), Spiritualism and occultism (Dixon, 2001; Owen, 2004; Treitel, 2004; Albanese, 2007; Wolffram, 2009; Noakes, 2019), early modernity (Clucas/Forshaw/Rees, 2011; Rampling, 2014; Copenhaver, 2015), magic and occult arts in the middle ages (Burnett, 1996; Pingree, 1997; Fanger, 2012), "esoteric" currents in antiquity (Turner, 2001; Dieleman, 2005; Bull, 2018), or within dynamic new fields such as global history (Bayly, 2004; Osterhammel, 2014; Conrad, 2018; Green, 2015).

In turn, we observe that there is a widespread tendency to only superficially engage with scholarship from outside the field, or to outright ignore it even when it is clearly relevant. The discussion of "global" esotericism is, again, a striking case in point. Neither Bogdan and Djurdjevic (2014) nor Hanegraaff (2015) have engaged with the vast literature on global, imperial, (post-)colonial, or related history. In the latter case especially, there is even a lack of engagement with scholarship or historical sources related to the respective geographical areas that serve as examples. It should be noted that this is the case despite repeated attempts to introduce a global perspective to the field (esp. Bergunder, 2010; 2014; 2016; cf. Strube, 2016).

This has become an especially pressing issue as critical arguments directed at these problems have not always been engaged with in a constructive manner. Instead, we now see polemical broadsides aimed against "those radical theorists who are so eager to deconstruct 'Western culture'" (Hanegraaff, 2019a, p. 151). A hazy "postmodernism" is framed as a dangerous "Establishment" opponent, while rallying around a problematic mix of cultural chauvinism (defending "Western") and oppositional posturing (protecting esoteric "rejected knowledge"). A particularly striking example is found in a recent polemic against what is regarded as "critical theory" and "those approaches associated" with it, published in the official Esswe newsletter (Hanegraaff, 2o1gb, p. 6).

Criticism or even rejection of certain approaches or scholarly traditions can be perfectly reasonable and is a vital part of scholarly debate. The kinds of reactions we have mentioned here, however, appear less interested in engaging with concrete scholarly arguments, which are absent due to the consistent lack of citations, than in reproducing politically charged polemical narratives embedded in a perceived "culture war." This volume unambiguously rejects these kinds of politicized polarization and instead seeks to offer new, balanced ap- 
proaches to broaden the scope of the study of esotericism and add substance to its theoretical-methodological toolkit. It should be noted that many of the critical discussions that our authors highlight have long been part of the debate in the humanities at large, and in religious studies specifically. In order to halt what we see as an ongoing self-marginalization of the study of esotericism in its tracks, it is high time that they are taken more seriously in our field as well.

The ambition of this book is thus to facilitate a deeper-going critical selfexamination, which we deem necessary for the current push into new regions, domains, and disciplines to succeed, but also for establishing the field more widely and solidly within its existing borders. The aim, to be sure, is not to urge esotericism scholars to change their subjects or to devalue their previous work, but rather to encourage an open and serious exchange with other perspectives, both within and beyond the field. Debating, reflecting, and possibly revising or abolishing key concepts in the study of esotericism must be an integral part of that process.

We have collected eleven chapters by scholars who could, by and large, be seen as belonging to an emerging new generation of esotericism specialists. All chapters address existing limitations, biases, or problems in the field, each in its own way, and each related to the scholar's area of expertise. It has also been important for us that each chapter provides constructive, forward-looking suggestions for how research practices might be improved. Several chapters deal with problems related to the Western demarcation-for this reason we have also spent some time introducing that particular problem in this introduction. Some chapters deal with problems related to how we conceptualize esotericism itself-especially in terms of rejected knowledge or diffusely defined "related currents" - while others address specific topical areas that remain undertheorized, such as issues of race and gender.

Dylan Burns' chapter addresses the old question of whether and, as the case may be, how esotericism might be usefully applied to the study of the ancient Mediterranean world. The religious and intellectual history of late antiquity is a field that overlaps considerably with the typical narratives of esotericism (e.g. "Renaissance esotericism" as custodian of Hermetism, theurgy, Platonist metaphysics, Gnosticism, etc.), but it has been able to flourish perfectly well without the use of that term. What could "esotericism" contribute to scholars of antiquity? Conversely, scholars of esotericism are frequently pointed back 
to late-antique materials by their very sources, but how should they talk about the link between (modern) esotericism and antiquity? In existing scholarship, this latter issue has often been handled through the mediation of fuzzy and promiscuous concepts like "gnosis" and, more recently, "Platonic orientalism." In "Receptions of Revelations: A Future for the Study of Esotericism and Antiquity," Burns provides a methodologically clear-sighted and cogently argued alternative: instead of looking for an emphasis of "gnosis" as salvific knowledge, perhaps associated with "altered states of consciousness," and using this to construct an esoteric lineage, scholars should adopt a strict form of reception history that follows the constantly changing uses of a plethora of late-antique texts into the Middle Ages, the Renaissance, and beyond. More specifically, Burns suggests that the term "esotericism" may still be useful in the ancient world if, taking a cue from Kocku von Stuckrad, we (1) see it as a "purposeful implementation of the dynamic of secrecy, concealment, and revelation," and (2) proceed to focus on how "revelatory knowledge" is legitimized in a crowded field of revelation-based claims to authority. This, Burns argues, would allow us to talk heuristically about "ancient (Mediterranean) esoteric traditions," but in a way that would necessitate expanding our relevant sources to include revelatory material that scholars of esotericism still pay little attention to, such as the Jewish apocalyptic tradition. Doing so would only be possible through a closer engagement with the thriving work by biblical scholars, who have long taken an interest in literature on secrecy, concealment, and the establishment of revelatory authority.

In the chapter "Towards the Study of Esotericism Without the "Western," Julian Strube interrogates the current debate on the "Western" in Western esotericism and argues unequivocally that the qualifier should be dropped. Noting that critique of the term's ideological baggage by now has a very long history across the humanities, Strube is unsatisfied with what attempts to introduce the same questions in esotericism research have yielded so far. $\mathrm{He}$ diagnoses recent responses to calls for discarding "Western" as a "diffusionist reaction," which depicts esotericism as a ready-made, unchanging European "export," an approach which conceals the agency of non-European actors. He also highlights that a thorough historicization of the term itself must lead to the conclusion that the construct "Western esotericism" has always been a polemical term with a global context, which continues to carry with it a baggage from occultist-internal debates from the turn of the previous century. We can do better, however: subtitled "Esotericism from the Perspective of a Global Religious History," Strube's chapter ends up arguing that the problems with esotericism research's lingering ethnocentrism, many of which became truly explicit only during recent discussions, can be overcome if we embed the 
study of esotericism in the framework of global religious history. The chapter ends with an overview of what global history entails, and concrete examples of its relevance to esotericism.

Islam is, as we have seen, an outstanding example of what Liana Saif calls the "exclusionary tendencies" expressed by the "Western" demarcation. In her chapter, Saif provides a historical overview of the division between East and West in the study of esotericism, highlighting that predominant narratives within the field sanitize orientalist perspectives. The notion of "Platonic orientalism" serves as a main example of that tendency. As Saif demonstrates, it relegates Islam to a "carrier civilization" while juxtaposing it to an ideologically charged narrative of the rise of "the West." This is not only ahistorical but also fails to take into account decades of scholarship on the intricacies of orientalism, which becomes most tangible in the popularity of the concept of "positive orientalism" in the field. Moreover, Saif examines how perennialist views of Islam have determined approaches to the subject, contradicting the many attempts to distance it from "religionist" perspectives. Arguing that the current approach to Islam is not sustainable, Saif calls for questioning the ahistorical, Europeanist narratives still informing scholarship on Islamic esotericism, and finally leaving them behind.

Mariano Villalba's contribution investigates another detrimental consequence of the "Western" demarcation, namely the de facto exclusion of South America and the Iberian Peninsula from its scope. This is especially instructive since Hanegraaff used the colonization of the Americas to assert the "globalization of Western esotericism." Villalba forcefully demonstrates the flaws of that perspective, by arguing that esotericism should not be viewed as a Western European phenomenon that spread to the colonies. The conquest of America decisively stimulated its emergence in the first place, and hence that emergence cannot reasonably be restricted to Europe. This is particularly significant as Villalba shows how "the West" has been restricted even within Europe, effectively removing the Iberian Peninsula from its sphere. Villalba introduces a decolonial approach to correct these distortions and unravels the cultural, racist, and ideological implications of the "Western" demarcation. The ambiguous relationship between European occultist perspectives and South American aboriginal traditions serves as an impressive illustration of how racial and cultural assumptions have shaped approaches to esotericism, not only historically but even today.

Exchanges between individuals across the globe have largely unfolded within the context of colonialism, particularly in the nineteenth century. In recent years especially, scholarly and public debates have strived to take this circumstance into account and highlight the role and agency of "non-Western" 
actors. The tendency arose, however, to frame such exchanges predominantly in terms of oppression and appropriation, for instance with regard to yoga. Ironically, this over-emphasis eclipsed the role of "non-Western" actors in ways similar to their outright neglect. Keith Cantú offers a critical analysis on this circumstance, discussing how more or less implicit assumptions of (pre-colonial) "authenticity" tend to obscure the contributions of South Asians to the emergence of modern yoga and related practices. Putting scholarship on esotericism into dialogue with the field of yoga studies, Cantú highlights the exceptional role of Theosophists and occultists for exchanges with South Asian authors and practitioners. Demonstrating that these exchanges were by no means unidirectional, Cantú argues for the fruitfulness of taking into account both the "local" and "translocal" dimensions of esoteric movements that defy clear differentiations between "authentic" or "inauthentic."

The conceptualization of esotericism as "rejected knowledge" is, as we have seen, one of the most pressing and problematic issues for the advancement of the field today. In his chapter, Egil Asprem provides a stringent criticism of this concept and highlights a range of problems resulting from the persisting lack of systematic reflection on its implications. Asprem argues that a "strict version" of the rejected knowledge model marked an important step within the field, as it shed light on early modern historiographies that had grouped specific currents and individuals together in a category that we today refer to as esotericism. However, Asprem demonstrates that there is also an "inflated version" of that model at work today, which effectively reproduces, rather than historicizes, these polemical narratives. In fact, the notion of a "Grand Polemical Narrative" running throughout "Western civilization" decidedly contributes to the self-marginalization of the field by maintaining an "oppositional" identity of both the subject matter and its scholarly study. Not only, then, does the inflated rejected knowledge model obscure much more complex developments and blur the lines between insider and academic perspectives. In its most problematic manifestations, it turns into outright polemics. Asprem's chapter is not only a potent analysis of the field's unexamined theoretical baggage, but it also proposes a way out of one of its central dilemmas by offering a more sophisticated toolkit to approach aspects such as heterodoxy, deviance, opposition, and marginalization.

In the chapter "Race and the Study of Esotericism," Justine Bakker starts with an observation that should have been obvious: that race matters in and for esotericism and its study. It matters in the formation of esoteric ideas and practices, and it matters for what scholars choose to focus on and which narratives they consequently tell. These basic insights have been almost entirely absent from scholarship on (Western) esotericism. When race appears as an 
analytic perspective, it is usually to identify unambiguously racist ideological formations among overwhelmingly white forms of esotericism, whether in the shape of Ariosophy or white-supremacist paganisms. As long as such studies remain the only race perspectives on offer, they obscure the fact that race (and racism) is a structural issue that shapes social practices-including the practice of academic research - in a variety of ways, both more and less subtle. It also reinforces the normativity of whiteness, obscuring that whiteness is also constructed through social practices. In her chapter, Bakker uses two case studies to illustrate how an analytic focus on race can bring new insights to the study of esotericism: (1) mediumistic contact with blacks, native Americans, and "great white men" in one white and one black Spiritualist community around the America Civil War era, and (2) processes of racialization in alien abduction narratives. The examples demonstrate how a critical perspective on race allows us to see both how race relations (including whiteness) are constructed in esoteric practices, and how these relate to broader societal realities related to race, but also how the "color line" in American society has influenced the religious experiences of blacks and, consequently, shaped and often twisted their representation in scholarship and the public imagination. Importantly, Bakker shows that there already exists a rich literature on these aspects of esoteric movements, but that all of it has been produced outside the field of esotericism, primarily by scholars in literary and cultural studies. The chapter is a call for esotericism scholars to follow their colleagues' lead and embrace tools from black studies, whiteness studies, and critical race theory to enhance their own work.

The aspect of race in the study of esotericism is further expanded in the chapter by Hugh R. Page, Jr. and Stephen C. Finley. Together with Margarita S. Guillory, they have co-edited Esotericism in African American Religious Experience (2015), a milestone for the study of esotericism that delineated the new field of Africana Esoteric Studies (AES). This field advances a trans-disciplinary approach that highlights the problems of the exclusionary tendencies expressed by both the "Western" demarcation of "Western esotericism" and its prominent conceptualization as "rejected knowledge." While the former effectively functions as a form of academic closure privileging an implicitly canonical set of sources and subjects, the latter neglects those people of color within and outside "the West" who were, first and foremost, rejected because of their bodies. AEs therefore directs attention to the idea of "rejected people" whose knowledge was cast aside precisely because of their embodiment. Page and Finley argue that their knowledge has been doubly concealed, not only academically through the conceptualization of "rejected knowledge" within "Western esotericism," but also through the historical fact that they have been forced 
to conceal and selectively disclose their knowledge to others. The chapter proposes an experimental interpretive method, flash non-fiction, to approach such secretly coded esoteric cultural artifacts. Page and Finley apply this method to African American Soul and Blues lyrics from the late 1960s to the early 1970s, a period marked by civic unrest. Through their analysis-and performancePage and Finely illustrate the role of African American artists as stewards, creators, and interpreters of esoterica, as well as the ways in which their artifacts become generators of context-specific Africana esoteric worldviews.

Given the extraordinary prominence and relevance of sexuality, sex, and gender for the subject of esotericism, it is telling that the field of "Western esotericism" has long been reluctant to engage, even superficially, with fields of study that are dedicated to these very aspects. As Manon Hedenborg White points out in her chapter on "Performativity and Femininity in the Cauldron of Esotericism Research," most research that has focused on the relationship between gender and esotericism has, indeed, been conducted outside the field. Through a close analysis of four rituals from the repertoire of Thelema, Hedenborg White demonstrates the fruitfulness of a sophisticated approach informed by gender and queer studies to grasp the many ambiguities and complexities arising from the role of sex and gender in esoteric contexts. The chapter's focus rests on different, and often contradictory, performances of femininities. While it touches the heart of debates that have been unfolding in gender-related studies for decades, Hedenborg White's adoption of the insights from those debates is not only innovative but also highly instructive. It is an impressive illustration of how the role of esoteric practices for challenging hegemonic gender logics and power relations can and should be investigated within the study of esotericism.

While esotericism is often associated with the rejected, the hidden, and the oppositional, today it is commonly packaged as glossy commodities and distributed to a growing global market of consumers. In "What Do Jade Eggs Tell Us about the Category of Esotericism," Susannah Crockford addresses the striking but surprisingly under-researched economic aspects of contemporary esotericism, lifting much bigger issues about how esoteric spiritualities function in the context of neoliberal consumer culture. Crockford starts from the observation that the vast majority of esotericism research is text based, and that even the few social science oriented approaches that exist have failed to address the material products of contemporary esotericism and the economic power relations in which they are embedded. Through the example of Gwyneth Paltrow's lifestyle company, Goop, which sells a variety of luxury commodities in areas ranging from fashion to wellness to complementary medicine, Crockford analyses how common esoteric tropes such as ancient 
wisdom, the revelation of secrets, subtle energies, and polemics against a materialist Establishment operate as strategies of branding and marketization within a massive global wellness industry with an estimated size of $\$ 4.2$ trillion in 2018. What does the perception of esotericism as "deviant," "rejected," or "secret/hidden" mean when it is mobilized in the neoliberal market economy? Crockford argues that analyses of contemporary esotericism ought to pay more attention to the economic relationships through which esotericism is developed, disseminated, and consumed today, which will force us to take a broader look at how the common rhetoric of the esoteric (e.g. about secrets, ancient wisdom, and anti-spiritual establishments) in fact functions to create and uphold unequal economic power relations.

The final chapter by Dimitry Okropiridze provides a philosophical interrogation of how scholars have defined "esotericism" over the past few decades. At the heart of Okropiridze's discussion is a philosophical paradox that he sees as unavoidable in all acts of interpretation, that is to say, whenever we connect a term to some phenomenon. In all acts of interpretation, Okropiridze argues, we have two and only two options: either we say that concepts determine the meaning of phenomena (putting epistemology before ontology), or we say that phenomena determine the meaning of concepts (putting ontology before epistemology). The latter position (which he calls onto-epistemological) is best exemplified by essentialist approaches, while the former (called epistemo-ontological) coheres closer with discursive and constructionist approaches. The paradox, as Okropiridze sees it, is that these two options (or vectors) are mutually exclusive, yet also both necessary for meaning to be successfully produced. The chapter applies these insights to reconstruct the progress of definitions of esotericism from Faivre (form of thought manifesting in discourse), through Hanegraaff (narratives and othering processes), to Bergunder (esotericism as empty signifier), to Asprem (assembly and labelling of cognitive building blocks), arguing that we see a series of pendulum switches from the onto-epistemological (Faivre) to the epistemoontological (Bergunder), with Hanegraaff unresolved in between, and Asprem attempting to reconcile the two through a merger of constructionist and naturalistic approaches. Due to what Okropiridze calls the antinomy of interpretation, however, such reconciliation is impossible. Instead, Okropiridze calls for a "varifocal theory of interpretation" that admits the incommensurability of onto-epistemology and epistemo-ontology, allows the two directionalities to exist side by side, and encourages scholars to become "questing commuters" between the two approaches.

Together, these chapters address some of the most pressing challenges in the study of esotericism today, and identify a few new ones to boot. They pro- 
vide a diagnosis of the theoretical state of the field and prescribe remedies which, we hope, will be adopted more systematically in the years ahead. The most significant remedy, as all chapters indicate, is to make "intedisciplinarity," "theory," and "method" more than just buzzwords. To overcome its presentday impasses and deliver on the promise of a more complex understanding of, e.g. modernity, "Western culture," or the relationships between religion, magic, and science, it seems to us that scholars of esotericism first and foremost have to read much broader and engage much wider and deeper with work carried out across the humanities and the social sciences than has so far been the case.

\section{Bibliography}

Albanese, C.L. (2007) A Republic of Mind and Spirit: A Cultural History of American Metaphysical Religion. New Haven/London: Yale University Press.

Asprem, E. (2014) "Beyond the West: Towards a New Comparativism in the Study of Esotericism," Correspondences, 2(1), pp. 3-33.

Asprem, E. (2021) "Rejected Knowledge Reconsidered: Some Methodological Notes on Esotericism and Marginality," in Asprem, E. and Strube, J. (eds.) New Approaches to the Study of Esotericism. Leiden and Boston: Brill, pp. 127-146.

Asprem, E. and Granholm, K., (eds.) (2013) Contemporary Esotericism. Sheffield: Equinox Publishing Ltd.

Asprem, E. and Dyrendal, A. (2015) "Conspirituality Reconsidered: How Surprising and How New Is the Confluence of Spirituality and Conspiracy Theory?," Journal of Contemporary Religion, 3o(3), pp. 367-382.

Asprem, E. and Davidsen, M. (2017) "Editor's Introduction: What Cognitive Science Offers the Study of Esotericism," Aries, 17(1), pp. 1-15.

Asprem, E. and Dyrendal, A. (2018). "Close Companions? Esotericism and Conspiracy Theories," in Dyrendal, A., Robertson, D., and Asprem, E. (eds.) Handbook of Conspiracy Theory and Contemporary Religion, pp. 207-233. Brill: Leiden.

Bakker, J.M. (2019) "Hidden Presence: Race and/in the History, Construct, and Study of Western Esotericism," Religion. DoI: 10.1080/0048721X.2019.1642262.

Bakker, J.M. (2021) "Race and (the Study of) Esotericism," in Asprem, E. and Strube, J. (eds.) New Approaches to the Study of Esotericism. Leiden and Boston: Brill, pp. 147-167.

Bayly, C.A. (2004) The Birth of the Modern World, 1780-1914: Global Connections and Comparisons. Malden/Oxford: Blackwell.

Bergunder, M. (2010) "What is Esotericism? Cultural Studies Approaches and the Problems of Definition in Religious Studies," Method and Theory in the Study of Religion, 22(1), pp. 9-36. 
Bergunder, M. (2014) "Experiments with Theosophical Truth: Gandhi, Esotericism, and Global Religious History," Journal of the American Academy of Religion, 82, pp. 398-426.

Bergunder, M. (2016) “'Religion' and 'Science' Within a Global Religious History," Aries, 16(1), pp. 86-141.

Bevir, M. (2000) "Theosophy as a Political Movement," in Copley, A. (ed.) Gurus and Their Followers. Delhi: Oxford University Press, pp. 159-179.

Bogdan, H. and Djurdjevic, G. (eds.) (2014) Occultism in a Global Perspective. Durham: Acumen Publishing.

Bogdan, H. and Hammer, O. (eds.) (2016) Western Esotericism in Scandinavia. Leiden: Brill.

Bubello, J.P. (2010) Historia del Esoterismo en Argentina. Buenos Aires: Editorial Biblos.

Bull, C. (2018) The Tradition of Hermes Trismegistus: The Egyptian Priestly Figure as a Teacher of Hellenized Wisdom. Leiden: Brill.

Burnett, C. (1996) Magic and Divination in the Middle Ages: Texts and Techniques in the Islamic and Christian Worlds. Aldershot: Variorum.

Burns, D. (ed.) (2015) Special Issue on Antiquity, Aries, 15(1).

Burns, D. (2021) "Receptions of Revelations: A Future for the Study of Esotericism and Antiquity," in Asprem, E. and Strube, J. (eds.) New Approaches to the Study of Esotericism. Leiden and Boston: Brill, pp. 20-44.

Cantú, K. (2021) “'Don't Take Any Wooden Nickles': Western Esotericism, Yoga, and the Discourse of Authenticity," in Asprem, E. and Strube, J. (eds.) New Approaches to the Study of Esotericism. Leiden and Boston: Brill, pp. 109-126.

Clucas, S., Forshaw, P.J., and Rees, V. (eds.) (2011) Laus Platonici Philosophi: Marsilio Ficino and his Influence. Leiden: Brill.

Conrad, S. (2018) "A Cultural History of Global Transformation," in Conrad, S. and Osterhammel, J. (eds.) A History of the World, vol. 4: An Emerging Modern World, 1750-1870. Cambridge: Harvard University Press, pp. 411-659.

Copenhaver, B. (2015) Magic in Western Culture: From Antiquity to the Enlightenment. Cambridge: Cambridge University Press.

Crockford, S. (2021) “What Do Jade Eggs Tell Us about 'Esotericism”? Spirituality, Neoliberalism, Secrecy, and Commodities," in Asprem, E. and Strube, J. (eds.) New Approaches to the Study of Esotericism. Leiden and Boston: Brill, pp. 201-216.

Crockford, S. and Asprem, E. (2018) "Ethnographies of the Esoteric: Introducing Anthropological Methods and Theories to the Study of Contemporary Esotericism," Correspondences, 6(1), pp. 1-23.

Dieleman, J. (2005) Priests, Tongues, and Rites: The London-Leiden Magical Manuscripts and Translation in Egyptian Ritual (100-30o CE). Leiden: Brill.

Dixon, J. (2001) Divine Feminine: Theosophy and Feminism in England. Baltimore/London: The Johns Hopkins University Press. 
Djurdjevic, G. (2014) India and the Occult: The Influence of South Asian Spirituality on Modern Western Occultism. New York: Palgrave.

Fanger, C. (ed.) (2012) Invoking Angels: Theurgic Ideas and Practices, Thirteenth to Sixteenth Centuries. University Park: Pennsylvania State University Press.

Finley, S., Guillory, M., and Page, H.R., Jr. (eds.) (2014) Esotericism in African American Religious Experience: “There Is a Mystery”... Leiden: Brill.

Granholm, K. (2013) "Locating the West: Problematizing the Western in Western Esotericism and Occultism," in Bogden, H. and Djurdjevic, G. (eds.) Occultism in a Global Perspective. London: Acumen Publishing.

Gray, B. (2019) "The Traumatic Mysticism of Othered Others: Blackness, Islam, and Esotericism in the Five Percenters," Correspondences, 7(1), pp. 201-237.

Green, N. (2015) “The Global Occult: An Introduction," History of Religions, 54(4), pp. $383-393$.

Hanegraaff, W.J. (2015) "The Globalization of Esotericism," Correspondences, 3(1), pp. $55^{-91 .}$

Hanegraaff, W.J. (2019a) "Rejected Knowledge... So You Mean that Esotericists Are the Losers of History?" in Hanegraaff, W.J., Forshaw, P.J., and Pasi, M. (eds.) Hermes Explains: Thirty Questions About Western Esotericism, pp. 145-152. Amsterdam: Amsterdam University Press, 2019.

Hanegraaff, W.J. (2019b) Interview in the Newsletter of the European Society for the Study of Western Esotericism. Available at: https://www.esswe.org/resources/pdf/ newsletter/ESSWE_Newsletter_2O19_Vol_10_No_1_2_Summer_Winter_2019.pdf (Accessed: July 27, 2020).

Hedenborg White, M. (2020) The Eloquent Blood: The Goddess Babalon \& the Construction of Femininities in Western Esotericism. Oxford: Oxford University Press.

Hedenborg White, M. (2021) "Double Toil and Gender Trouble? Performativity and Femininity in the Cauldron of Esotericism Research," in Asprem, E. and Strube, J. (eds.) New Approaches to the Study of Esotericism. Leiden and Boston: Brill, pp. 182-200.

Melvin-Koushki, M. and Gardiner, N. (eds.) (2017) "Islamicate Occultism: New Perspectives," Special Issue of Arabica, 64(3-4), pp. 287-693.

Noakes, R. (2019) Physics and Psychics. Cambridge: Cambridge University Press.

Okropiridze, D. (2021) "Interpretation Reconsidered: The Definitional Progression in the Study of Esotericism as a Case in Point for the Varifocal Theory of Interpretation," in Asprem, E. and Strube, J. (eds.) New Approaches to the Study of Esotericism. Leiden and Boston: Brill, pp. 217-240.

Osterhammel, J. (2014) The Transformation of the World: A Global History of the Nineteenth Century. Princeton: Princeton University Press.

Owen, A. (2004) The Place of Enchantment: British Occultism and the Culture of the Modern. Chicago: University of Chicago Press. 
Page, H.R. Jr. and Finley, S.C. (2021) “'What Can the Whole World Be Hiding?' Exploring Africana Esotericisms in the American Soul-Blues Continuum," in Asprem, E. and Strube, J. (eds.) New Approaches to the Study of Esotericism. Leiden and Boston: Brill, pp. 168-181.

Pasi, M. (2010) "Oriental Kabbalah and the Parting of East and West in the Early Theosophical Society," in Huss, B., Pasi, M., and Stuckrad, K.v. (eds.) Kabbalah and Modernity: Interpretations, Transformations, Adaptations, pp. 151-166. Leiden: Brill, 2010.

Pingree, D. (1997) From Astral Omens to Astrology: From Babylon to Bīkāner. Rome: Istituto italiano per l'Africa et l'Oriente/Herder.

Principe, L. (2012) The Secrets of Alchemy. Chicago: University of Chicago Press.

Rampling, J. (2014) “A Secret Language: The Ripley Scrolls," in Kerssenbrock-Krosigk, D.v., Wismer, B., Dupré, S. and Hachmann, A. (eds.) Art and Alchemy: The Mystery of Transformation, pp. 38-45. Düsseldorf: Hirmer/Museum Kunstpalast.

Roukema, A. and Kilner-Johnson, A. (2018) "Editorial: Time to Drop the 'Western," Correspondences, 6(2), pp. 109-115.

Saif, L. (2019) "What is Islamic Esotericism?" Correspondences: Journal for the Study of Esotericism, 7(1), pp. 1-59.

Saif, L. (2021) “That I Did Love the Moore to Live with Him': Islam in/and the Study of 'Western Esotericism," in Asprem, E. and Strube, J. (eds.) New Approaches to the Study of Esotericism. Leiden and Boston: Brill, pp. 67-87.

Stengel, F. (2011) Aufklärung bis zum Himmel: Emanuel Swedenborg im Kontext der Theologie und Philosophie des 18. Jahrhunderts. Tübingen: Mohr Siebeck.

Strube, J. (2016) Sozialismus, Katholizismus und Okkultismus im Frankreich des 19. Jahrhunderts: Die Genealogie der Schriften von Eliphas Lévi. Berlin/Boston: De Gruyter.

Strube, J. (2016) "Transgressing Boundaries: Social Reform, Theology, and the Demarcations Between Science and Religion," Aries, 16(1), pp. 1-11.

Strube, J. (2017) "Occultist Identity Formations Between Theosophy and Socialism in Fin-de-Fiècle France," Numen, 64(5-6), pp. 568-595.

Strube, J. (2021) “Towards the Study of Esotericism without the 'Western'”: Esotericism from the Perspective of a Global Religious History," in Asprem, E. and Strube, J. (eds.) New Approaches to the Study of Esotericism. Leiden and Boston: Brill, pp. $45^{-66 .}$

Strube, J. (forthcoming) “Theosophy, Race, and the Study of Esotericism," Journal of the American Academy of Religion.

Stuckrad, K.v. (2005) "Western Esotericism: Towards an Integrative Model of Interpretation," Religion, 34, pp. 78-97.

Stuckrad, K.v. (2008) "Esoteric Discourse and the European History of Religion: In Search of a New Interpretational Framework," in Ahlbäck, T. (ed.) Western Esotericism: Based on Papers read at the Symposium on Western Esotericism, Held at Åbo, 
Finland on 15-17 August 2007. Åbo: Donner Institute for Research in Religious and Cultural History.

Stuckrad, K.v. (2012) "Rejected Theory in the Study of Esotericism," Keynote Lecture at the ist International Conference on Contemporary Esotericism, Stockholm University, Sweden, August 27-29, 2012.

Thorndike, L. (1923-1958) A History of Magic and Experimental Science, 8 vols. New York: Columbia University Press.

Treitel, C. (2004) A Science for the Soul: Occultism and the Genesis of the German Modern. Baltimore: The Johns Hopkins University Press.

Turner, J.D. (2001) Sethian Gnosticism and the Platonic Tradition. Québec/Leuven: Université Laval/Peeters.

Veer, P.v.d. (2001) Imperial Encounters: Religion and Modernity in India and Britain. Princeton: Princeton University Press.

Villalba, M. (2021) "The Occult Among the Aborigines of South America? Some Remarks on Race, Coloniality, and the West in the Study of Esotericism," in Asprem, E. and Strube, J. (eds.) New Approaches to the Study of Esotericism. Leiden and Boston: Brill, pp. 88-108.

Viswanathan, G. (1998) Outside the Fold: Conversion, Modernity, and Belief. Princeton: Princeton University Press.

Wolffram, H. (2009) The Stepchildren of Science: Psychical Research and Parapsychology in Germany. Amsterdam/New York: Rodopi.

Yates, F. (1964) Giordano Bruno and the Hermetic Tradition. London: Routledge and Kegan Paul. 